
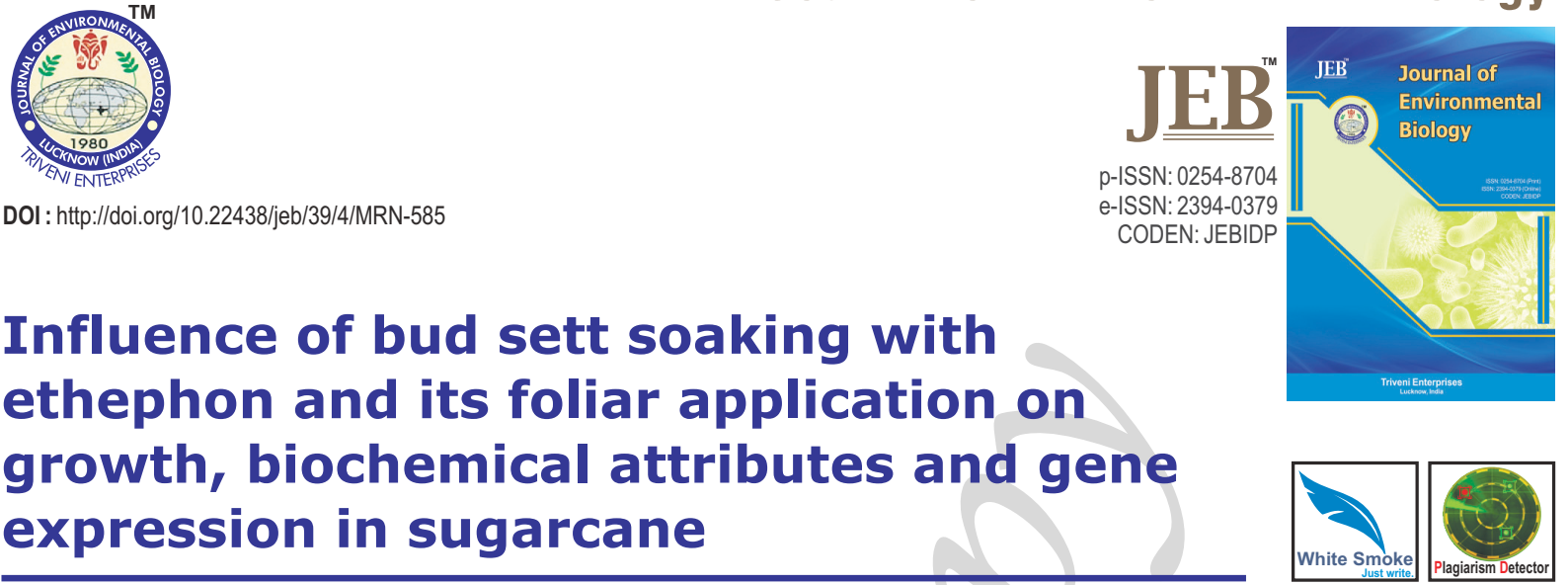

\title{
Influence of bud sett soaking with ethephon and its foliar application on growth, biochemical attributes and gene expression in sugarcane
}

Authors Info

\section{R. Jain*, A. Singh, S.P. Singh and $A$. Chandra}

Plant Physiology and Biochemistry Division, ICAR- Indian Institute of Sugarcane Research, Lucknow-226 002, India

${ }^{*}$ Corresponding Author Email radha_dinesh@yahoo.co.in

Key words

Bud sprouting

Ethephon

Gene expression

Sett priming

Sugarcane

Publication Info

Paper received : 06.02.2017

Revised received : 05.07.2017

Re-revised received : 11.12 .2017

Accepted: 13.12.2017

\section{Abstract}

Aim : The present study was carried out to evaluate the effect of sett soaking and foliar application of Ethephon treatment on sprouting, early growth characteristics, SAI and SPS gene expression in bud and leaf tissues and important physio-biochemical parameters which essentially regulate the process of shoot and root growth in sugarcane.

Methodology : Single bud setts of sugarcane were initially primed with graded level of Ethephon viz., 0 , 100,200 and 400 ppm for 24 hrs along with untreated control and planted in soil tray culture under net house. Data on bud sprouting, growth attributes were determined after 10 days. About 45 days after planting, second application of Ethephon was performed through foliar spray. Data on plant growth, sugar content, photosynthetic pigments, proline, total phenol and activity of peroxidase and nitrate reductase were estimated. SAI and SPS gene expression was also studied using gene specific primer pairs through qRT-PCR

Results : Ethephon treatment showed early and higher rate of bud sprouting, improved plant vigor, stalk height, fresh weight of root and shoot. Plants exposed to Ethephon exhibited higher chlorophyll content, proline, total phenol contents, activity of soluble acid invertase, nitrate reductase in vivo and peroxidase enzymes as compared to untreated plants. SAI and SPS gene expression was upregulated in treated bud and leaf tissues, respectively.

Interpretation : Ethephon showed stimulatory effects on bud sprouting and early growth characteristics by modulating sugar hydrolysis and its transport to growing shoot and improving photosynthetic pigments and activity of nitrate assimilating enzyme in sugarcane plants.

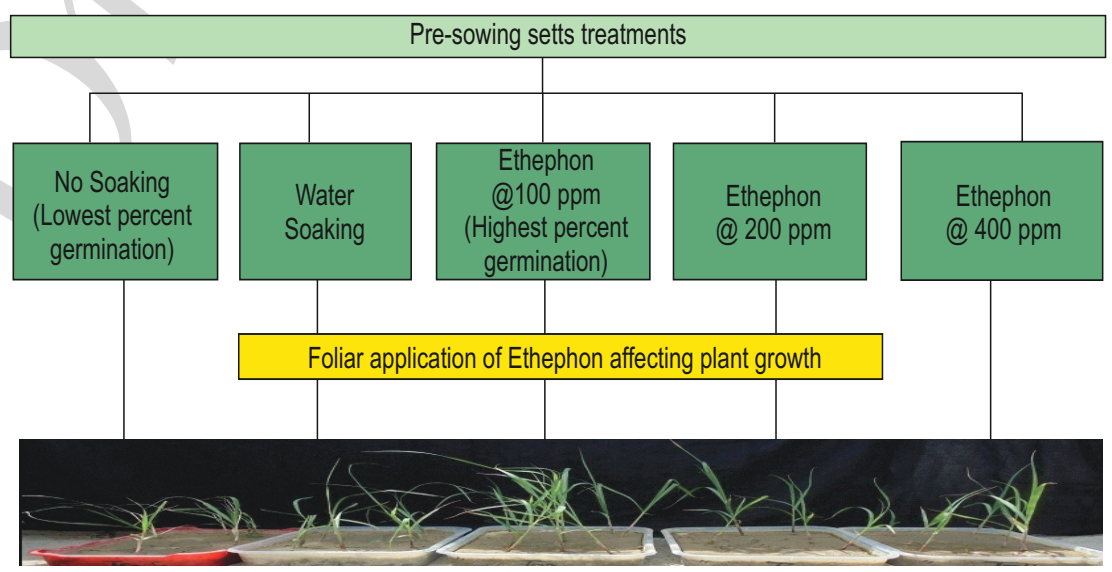




\section{Introduction}

Sugarcane, a $\mathrm{C}_{4}$ plant, is one of the most photosynthetically efficient crops, fixing $2-3 \%$ of solar radiation and producing over 100 tons of green matter every year, which is more than twice the agricultural yield of most other commercial crops (Almazan et al., 2001). Traditionally, sugarcane is used as a source of sweetener, it is an excellent ideal raw material for the bioenergy (co-generation), biofuels (ethanol, butanol) and cellulose based fuels and range of chemicals.

Ethephon or 2-CEPA (2-chloroethyl phosphonic acid), an ethylene generating compound is a multifaceted plant growth regulator. Its application varies with plant species, concentration and time of application. Ethephon regulates plant growth and development by applying it at various growth sites (Kidd and James, 1991). Ethephon is rapidly metabolized in plants, soils via hydrolysis, producing ethylene gas, phosphoric and hydrochloric acid; these products are naturally found in all plants as non-toxic chemicals. Ethylene has been implicated as a hormone that controls the time of seed germination, rate and dimensions of seedling growth, leaf expansion and expression of stress-related effects in plants (Fiorani et al., 2002; Khan, 2005; Jain et al., 2014; Iqbal et al., 2017). Ethephon is not only applied as an effective chemical ripener but also used to promote cane growth by soaking seed canes before planting or spraying at low concentration on the leaves at early growth stage of sugarcane (Solomon et al., 1998; Li, 2004). Many beneficial response of ethephon application on sucrose metabolizing enzymes has been reported earlier in sugarcane plants (Jain et al., 2014) and ratoon crop (Leite et al., 2009). Cunha et al. (2017) observed differential response of ethephon on sucrose level and sucrose synthase activity in sugarcane internodes during ripening which indicates ethylene as a potential regulator of sink strength. Present study was directed to evaluate the effect of soaking and foliar application of ethephon treatment on sprouting, early growth characteristics, and important physio-biochemical parameters which essentially regulate the process of shoot and root growth in sugarcane. An attempt was also made to study the effect of ethephon on soluble acid invertase and sucrose phosphate synthase gene expression through qRT-PCR using total RNA extracted from bud and leaf tissues after setts soaking in ethephon and its foliar application.

\section{Materials and Methods}

To study the effect of ethephon on bud sprouting, early growth characteristics and related biochemical attributes; experiments were conducted on overnight soaking of setts in graded level of ethephon using sugarcane variety CoLk 94184. Experiment comprises of 5 treatments : Control (T1), water soaked (T2), Ethephon @ 100 ppm (T3), Ethephon @ 200 ppm (T4) and Ethephon @ 400 ppm (T5). Bud tissues of treated and untreated control setts were analyzed for sugars, total phenol and soluble acid invertase (SAI) activity at 0 day. Next day after soaking, treated cane setts were planted in different trays filled with soil at uniform depth. These trays were maintained in nethouse conditions (day temperature $31.1-37.6^{\circ} \mathrm{C}$; night temperature $15.6-19.7^{\circ} \mathrm{C}$ ). Drainage was provided and trays were watered at alternate days. Six days after planting (DAP), sprouted buds were sampled for analysis of root and bud growth, sugars, total phenol and activity of SAl in bud tissues. Data on bud sprouting were recorded at 10, 14 and 18 days after planting. About 45 days after planting (DAP), foliar applications of different concentrations of ethephon were performed to these plants to investigate the changes in growth and biochemical attributes. Details of treatment for foliar application are as follows : No spray (T1), water spray (T2), Ethephon @ 100 ppm spray (T3), Ethephon @ 200 ppm spray (T4) and Ethephon @ 400 ppm spray (T5).

Seven days after foliar application, plants were sampled for growth characteristics and biochemical attributes. Fresh leaves were used for analysis of sugars, chlorophyll content, phenol, proline and peroxidase activity.

Chlorophyll content : Chlorophyll content was estimated by the method described by Arnon (1949). Fifty milligram fresh leaf material was homogenized in $80 \%$ acetone containing pinch of calcium carbonate and centrifuged for $10 \mathrm{~min}$. The supernatant was collected and absorbance was read at $663 \mathrm{~nm}$ and $645 \mathrm{~nm}$ spectrophotometrically. Chlorophyll contents were calculated using the formula given below and the amounts were calculated as $\mathrm{mg} \mathrm{g}^{-1}$ f.wt. of leaf:

$$
\begin{aligned}
& \text { Chlorophylla }=\left(\left(12.7 \times A_{663}\right)-\left(2.69 \times A_{645}\right)\right) \times 0.1 \\
& \text { Chlorophyll } b=\left(\left(22.9 \times A_{645}\right)-\left(4.68 \times A_{663}\right)\right) \times 0.1
\end{aligned}
$$

Peroxidase assay : Peroxidase activity was estimated by the modified method of Luck (1963). Enzyme extract for peroxidase was prepared by grinding fresh leaf tissues in liquid nitrogen, followed by solubilization with $5 \mathrm{ml}$ phosphate buffer ( $\mathrm{pH} 7.5)$ containing $0.1 \mathrm{M}$ EDTA. Homogenate was centrifuged for $10 \mathrm{~min}$ at $4^{\circ} \mathrm{C}, 12,000 \mathrm{rpm}$ and the supernatant was used as enzyme extract. Reaction mixture containing $0.1 \mathrm{ml}$ aliquot, $5 \mathrm{ml}$ sodium phosphate buffer $(1.0 \mathrm{M}), 1 \mathrm{ml} \mathrm{H}_{2} \mathrm{O}_{2}(0.01 \%)$ and $1 \mathrm{ml} \mathrm{p}$ phenylenediamine $(0.5 \%)$ was mixed thoroughly by shaking. After $5 \mathrm{~min}, 2 \mathrm{ml} 5 \mathrm{~N} \mathrm{H}_{2} \mathrm{SO}_{4}$ (stopping reagent) was added in sample tubes. All tubes were incubated at $4^{\circ} \mathrm{C}$ for an hour. Absorbance was measured at $485 \mathrm{~nm}$ using UV-VIS spectrophotometer (Motras Scientific, India). Peroxidase activity was expressed as change in OD mg ${ }^{-1}$ protein.

Quantification of proline content : Proline was determined in fresh leaves by the method of Bates et al. (1973) with minor modifications. Samples (200 mg f.wt.) were extracted in $2 \mathrm{ml}$ $3 \%(\mathrm{w} / \mathrm{v})$ sulphosalicylic acid, centrifuged the samples at 6000 rpm and collected supernatant for proline estimation. Reaction mixture containing $1 \mathrm{ml}$ aliquot, $2 \mathrm{ml}$ ninhydrin reagent and $2 \mathrm{ml}$ acetic acid were heated for $30 \mathrm{~min}$ and after cooling at room temperature, $5 \mathrm{ml}$ toluene was added to extract color by vertex mixing. The upper toluene phase was transferred into a dry glass tubes and the absorbance was measured at $520 \mathrm{~nm}$ using UV-VIS Spectrophotometer 
(Motras Scientific, India). Proline content was expressed as $\mu \mathrm{g}$ proline $100 \mathrm{mg}^{-1}$ f.wt.

NR in vivo assay : To determine the activity of NR in vivo, fresh leaf discs $(200 \mathrm{mg}$ ) were incubated in $0.005 \mathrm{M}$ phosphate buffer (pH 7.0) containing $0.1 \% \mathrm{KNO}_{3}$ and $0.1 \%$ isopropyl alcohol for $1 \mathrm{hr}$ in dark at room temperature (Radin, 1973). After $1 \mathrm{hr}$, enzyme mixture $(1 \mathrm{ml})$ was mixed with $1 \mathrm{ml}$ sulphanilamide (1\% sulphanilamide in $25 \% \mathrm{HCl}$ ) and $1 \mathrm{ml} \mathrm{NDD}$ (Naphthyl Ethylenediamine) solution (0.02\%) and $1.6 \mathrm{ml}$ distilled water in fresh tubes. Absorbance of color developed was measured at 540 nm using UV-VIS Spectrophotometer (Motras Scientific, India). NR activity was expressed as $\mu \mathrm{g}$ nitrite produced $100 \mathrm{mg}^{-1} \mathrm{f}$.wt.

Isolation of RNA : Total RNA was isolated in bud (6 DAP) and leaf tissues (60 DAP) using Qiagen RNeasy plant Mini kit as per manufacturer instruction. DNA contamination was removed by using RNAse free DNase kit (Qiagen). RNA samples were stored at $-20^{\circ} \mathrm{C}$ for further analysis. The amount of RNA was quantified using Nanodrop UV spectrophotometer (Quawell Q3000, USA) and quality was checked on $0.8 \%$ agarose gel after gel electrophoresis.

Expression analysis of SPS and SAI genes : Semi-quantitative RT-PCR (qRT-PCR) was performed for SAl and SPS gene expression in bud and leaf tissues using SAI (Chandra et al., 2010) and SPS gene (Verma et al., 2011) specific primer sequences, SAl forward : GTGCTCATCTGCATTGCTGT; SAl reverse CTTGTGCCAATTGTTGTGG, SPS forward: GGTGGTCAGGTGAAATATGTTG and SPS reverse: CGTTGAGTGCCCCAGACAG. qRT-PCR was performed in a PCT200 thermal cycle using equal amounts of RNA (200 ng), Qiagen one step RT-PCR kit and gene specific primer, both forward and reverse primers as follows: $50^{\circ} \mathrm{C}$ for $30 \mathrm{~min}$ for reverse transcription reaction, $95^{\circ} \mathrm{C}$ for $15 \mathrm{~min}, 94^{\circ} \mathrm{C}$ for $1 \mathrm{~min}, 58^{\circ} \mathrm{C}$ for $1 \mathrm{~min}, 72^{\circ} \mathrm{C}$ for $1 \mathrm{~min}$ for 32 cycles and final extension at $72^{\circ} \mathrm{C}$ for $10 \mathrm{~min}$. Amplification products were checked on $1.6 \%$ agarose gel and visualized by gel documentation system (AIPha Innotech). Integrated density value (IDV) of PCR product was measured using AlphaEase software supplied fromAlpha Innotech.

\section{Results and Discussion}

At about 24 hrs of ethephon treatment, concentration of both reducing and non reducing sugars were higher in treated buds as compared to control and water soaked treatment, indicating higher availability of soluble sugars compared to untreated control buds (Fig.1). The highest increase in reducing sugars $(30.35 \%)$ and total sugars $(29 \%)$ over control was at $100 \mathrm{ppm}$ ethephon level. The results of this study suggested that SAl activity in ethephon treated buds has been found to be higher (from $23 \%$ to $94 \%$ ) as compared to control and water soaked treatment and the most prominent increase ( $94 \%$ over control) was at 100 ppm level. Similar changes were reported earlier in sprouted bud of sugarcane bud chips soaked in ethephon and calcium chloride (Jain et al., 2011) and in coneflower species (Qu et al., 2004; Sari et al., 2001). Increase in SAl activity in sprouted bud indicates higher rate of sucrose (nonreducing sugar) hydrolysis and greater availability of free hexoses (reducing sugars) to the growing apical meristem due to ethephon treatment (Solomon et al., 1998; Cunha et al., 2017). In ethylenetreated potato tubers, Foukaraki et al. (2012) observed higher respiration activity and total sugars content which confirmed that the increase in total sugar content and SAI activity might be strengthened by exogenous ethylene application (Dai et al. 2016). Total phenol content of treated soaked buds increased due to ethephon treatment, highest increase $(17.74 \%)$ was obtained at lower concentration of ethephon (100 ppm). However, at 400 ppm ethephon, total phenol content showed marked reduction in bud tissues (Jain et al., 2014). Liu et al. (2013) also reported increase in total phenols of mung sprouts treated with variable ethephon concentrations (@25 to 100 ppm).

Graded concentrations of ethephon increased reducing sugar contents (by 4 to $43 \%$ ), non-reducing sugars (by 2 to $20 \%$ ) and total sugars contents (by 2 to $23 \%$ ) quantitatively as compared to untreated control and water soaked treatment after 6 days of planting (Fig 1). Increase in sugar content indicates the positive effect of ethephon on plant growth and development (Kidds and James, 1991; Khan et al., 2015; Iqbal et al., 2017) due to higher availability of free sugars in sprouted bud (Jain et al., 2010). Ethephon treated bud showed an increase in SAI activity by $2 \%$ to $36 \%$, thus resulted in improved bud sprouting and better bud growth; this increase was most pronounced at $100 \mathrm{ppm}$ ethephon treatment (Fig. 1). Earlier studies reported that low concentration of ethephon treatment promoted the activity of soluble acid invertase and neutral invertase in the stalk internodes at booming stage of sugarcane (Yao etal., 2000; Li, 2004).

Treated setts showed higher bud sprouting than untreated control and water soaked treatment; maximum percentage of bud sprouting (90\% at $10 \mathrm{DAP}$ and $100 \%$ at 14 and 18DAP, respectively) was recorded at $100 \mathrm{ppm}$ ethephon. Ethephon significantly increased the shoot weight from 60 to $166 \%$ and root weight from 14 to $71 \%$ as compared to untreated control treatment and water soaked treatment; highest increase was at $100 \mathrm{ppm}$ level. Earlier studies carried out in sub tropical india using ethephon as growth promoter have shown stimulatory effects of ethephon on the sprouting of sugarcane setts, bud chip seed stocks, stubble buds sprouting in winter initiated ratoon and mung bean (Solomon et al., 2001; Li, 2004; Jain and Solomon, 2010; Liu et al., 2013; Jain et al., 2014). In the present investigation, high content of total phenol (by 24 to $82 \%$ ) was observed in bud tissues of treated plants. Ethylene is known to accumulate flavanoids, catchin and epicatechin in lettuce, which are readily oxidized by polyphenol oxidase activity (Ke and Saltveith, 1988). Higher soluble phenolic content and polyphenol oxidase activity were observed earlier in rice due to longer exposure to ethylene hormone (Peng and Yamauchi, 1993) and 100 ppm ethephon treatment in mung bean (Liu et al., 2013). After about 45 days of planting, plants were sprayed with graded levels of ethephon. Treated plants showed significant increase in root and shoot 
Effect of ethephon on sugarcane sprouting and gene expression
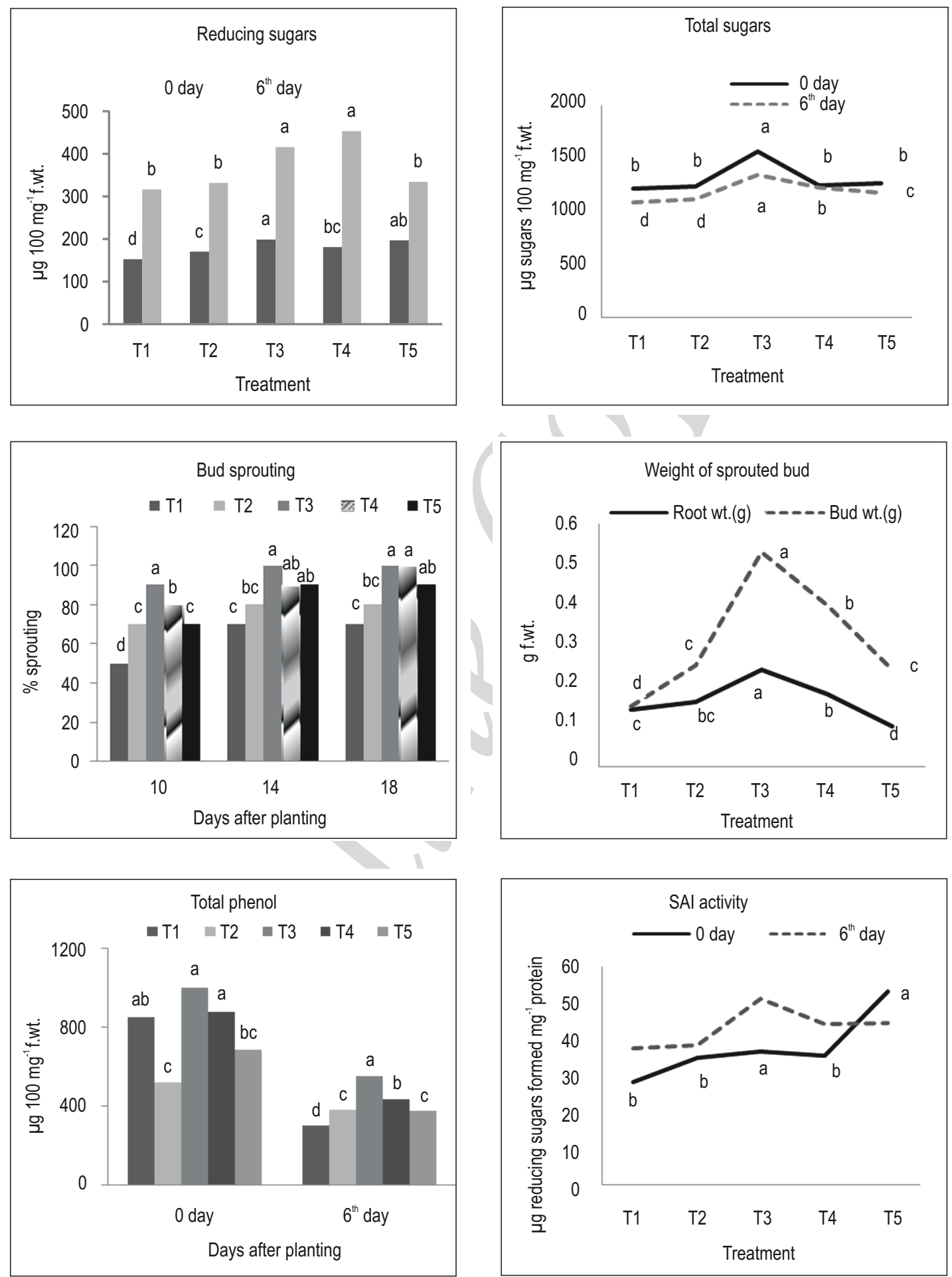

Fig. 1 : Effect of ethephon on bud sprouting and biochemical attributes of sugarcane; Mean values with different letters indicate significant $(P=0.05)$ differences between treatments; T1 : control, T2 : water soaked, T3 : Ethephon 100 ppm, T4 : Ethephon 200 ppm and T5 : Ethephon 400 ppm 

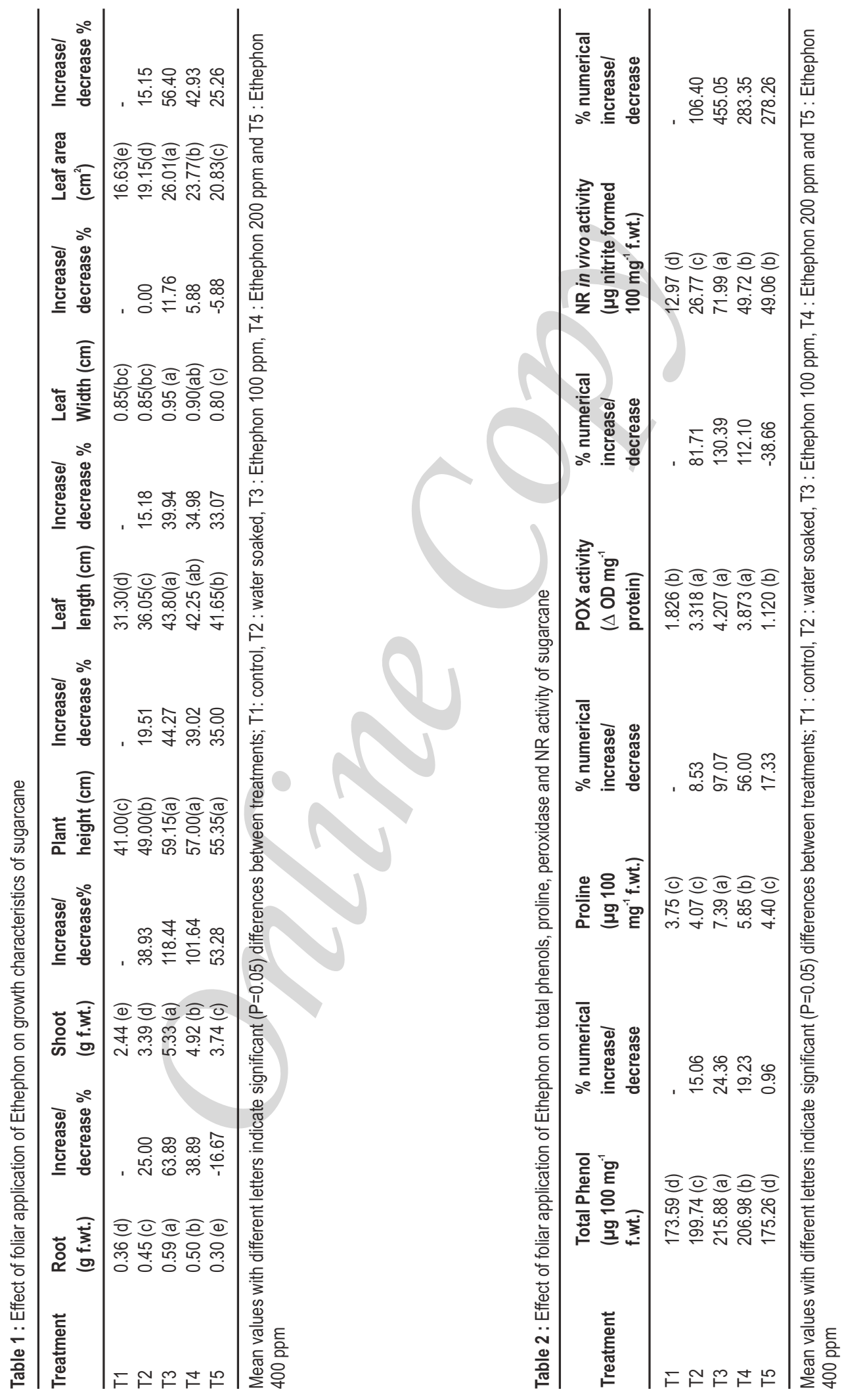

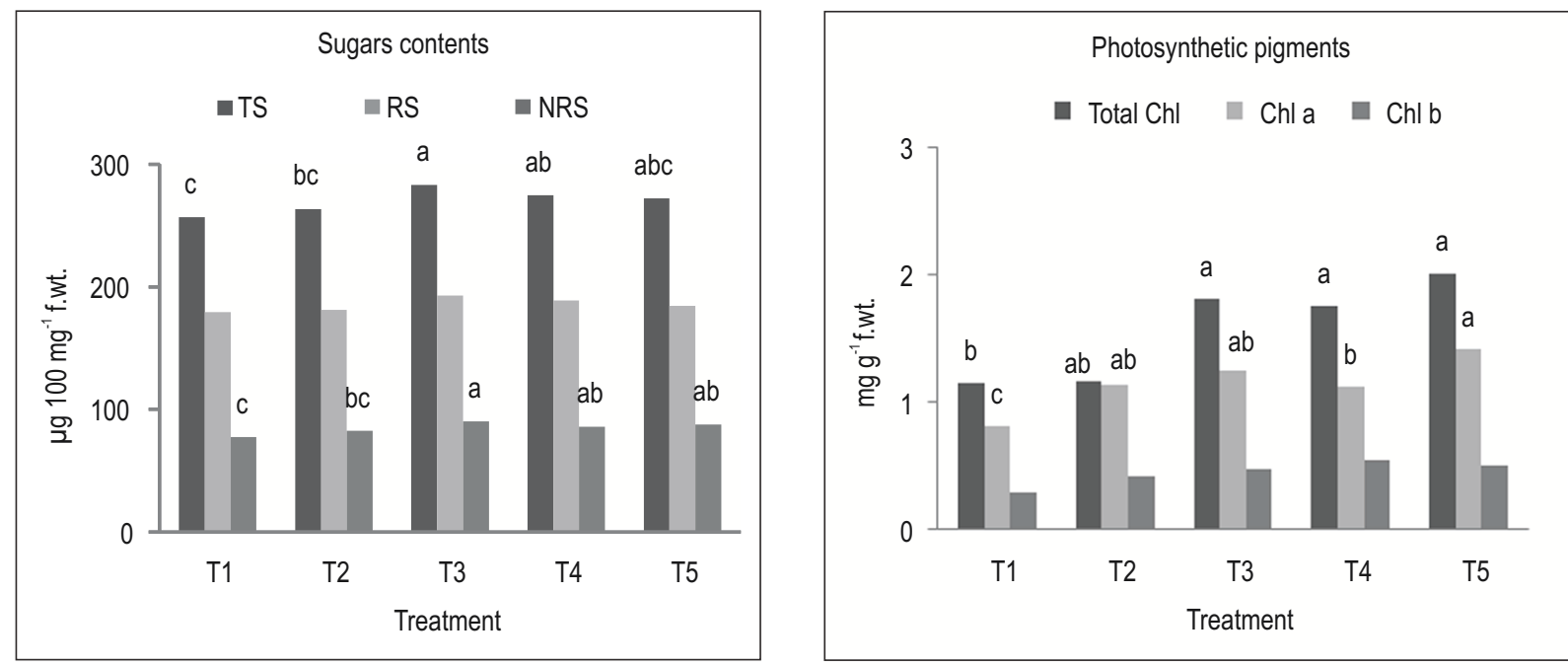

Fig 2 : Effect of foliar application of ethephon on sugars and photosynthetic pigments of sugarcane; Mean values with different letters indicate significant $(\mathrm{P}=0.05)$ differences between treatments; $\mathrm{T} 1$ : control, T2 : water soaked, T3 : Ethephon $100 \mathrm{ppm}, \mathrm{T} 4$ : Ethephon $200 \mathrm{ppm}$ and T5 : Ethephon 400 ppm

weight, plant height, leaf length, width and leaf area, increase was highest at 100 ppm ethephon level (Table 1). Increase over control was comparatively higher in shoot weight (by 118\%) than root weight (by 64\%). Reports are also available on stimulatory effect of ethylene on root activity by enhancing auxins contents in mung bean (Pan et al., 2002) and mustard (lqbal et al., 2017). Love et al. (2009) demonstrated ethylene as an endogenous regulator of meristem growth in Populus which stimulated xylem growth by means of cambial cell division.

Reducing sugars, non-reducing sugars and total sugars were comparatively higher in ethephon treated sugarcane leaves, maximum contents were obtained at 100 ppm ethephon treatment (Fig. 2). Similarly, ethephon treated plants showed higher chlorophyll a, b and total chlorophyll contents as compared to control and water treated plants (Fig. 2). Low concentration of ethephon treatment has a positive effect on chlorophyll synthesis, stomatal conductance, carbonic anhydrase, carboxylic acid synthase and rate of photosynthesis in mustard (Grewal et al., 1993; Khan et al., 2008; Iqbal et al., 2017) and in sugarcane (Jain and Solomon, 2010; Li, 2004). Increased chlorophyll contents in ethephon treated plants might be due to broadening of exterior mesophyll cells and chloroplast arrangements (Luo et al., 1997).

Ethephon showed increased total phenol content (by 1.0 to $24 \%$ ) and specific activity of peroxidase (by 112 to $130 \%$ ) over control in leaf tissues of treated plants; maximum increase was observed at $100 \mathrm{ppm}$ concentration (Table 2). Peroxidase enzyme is related to many important physiological processes such as auxin metabolism, cell differentiation, tissue maturation and adaptability of plants to the environmental stress (Lidija et al., 2017). It is well known that the expression of peroxidase in plant cells is controlled by ethylene (Retig and Rudich, 1972; Ingemarsson, 1995; Liu et al., 2013). Earlier studies have reported that ethephon increases peroxidase activity in spinach, sugarcane and mung bean (Ozturk and Demir, 2003; Li, 2004; Liu et al., 2013) and decreased IAA oxidase activity (Yao et al., 2000a).

The ethephon treatment significantly increased the activity of nitrate reductase in vivo by 278 to $465 \%$. The results of the present investigation are in agreement with those presented by Solomon et al. (1988) in sugarcane and by Joshi et al. (2011) in Jatropha. The increase in NR activity by foliar application of ethephon may be due to the modulations in the membrane permeability, activation of several enzyme activities, glycolysis acceleration and increased adenylic pool, polysomes and rRNA contents (Palmer, 1985; Pujade-Renaud et al., 1994; Joshi et al., 2011; Khan etal., 2015; Iqbal et al., 2017).

Proline content was relatively higher (from 17 to 97\%) in ethephon treated plants than untreated control plants; ethephon @100 ppm showed highest proline content. Similarly, Ozurtk and Damir (2003) observed increased proline content in pea epicotyls due to ethephon treatment. Proline is an important parameter of stress tolerance capacity of plants (Dash and Panda, 2001). Apart from acting as an osmolyte for osmotic adjustment, proline has been assigned for stabilizing sub-cellular structures, scavenging free radicals and buffering cellular redox potential under stress conditions (Ashraf and Foolad, 2007; Joshi et al., 2011).

Ethephon is known to improve sucrose content in sugarcane plants and sucrose accumulation is regulated by sucrose metabolizing enzymes, SPS, SAI and SS. In the present 


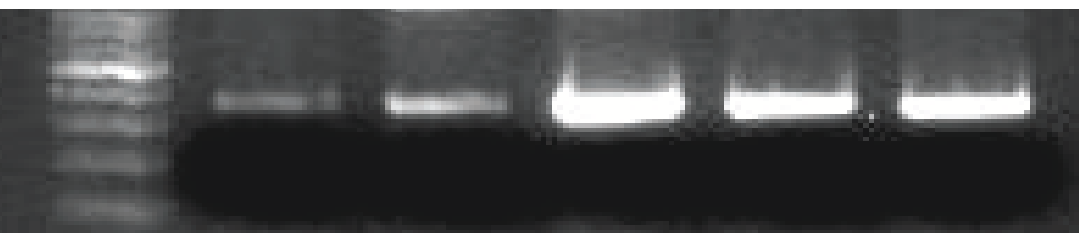

SAl gene expression in bud

A.

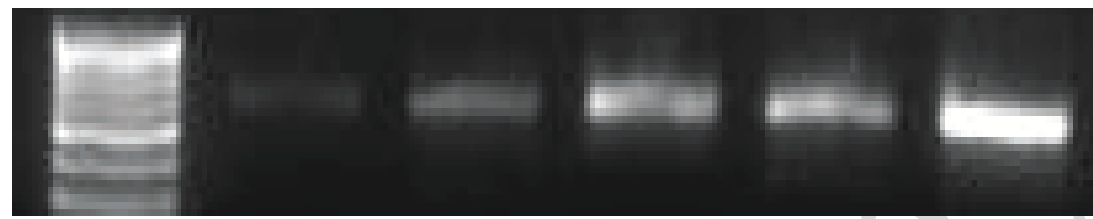

SPS gene expression in leaf

B.

$\mathrm{T} 1$

$\mathrm{T} 2$

T3

T4

T5
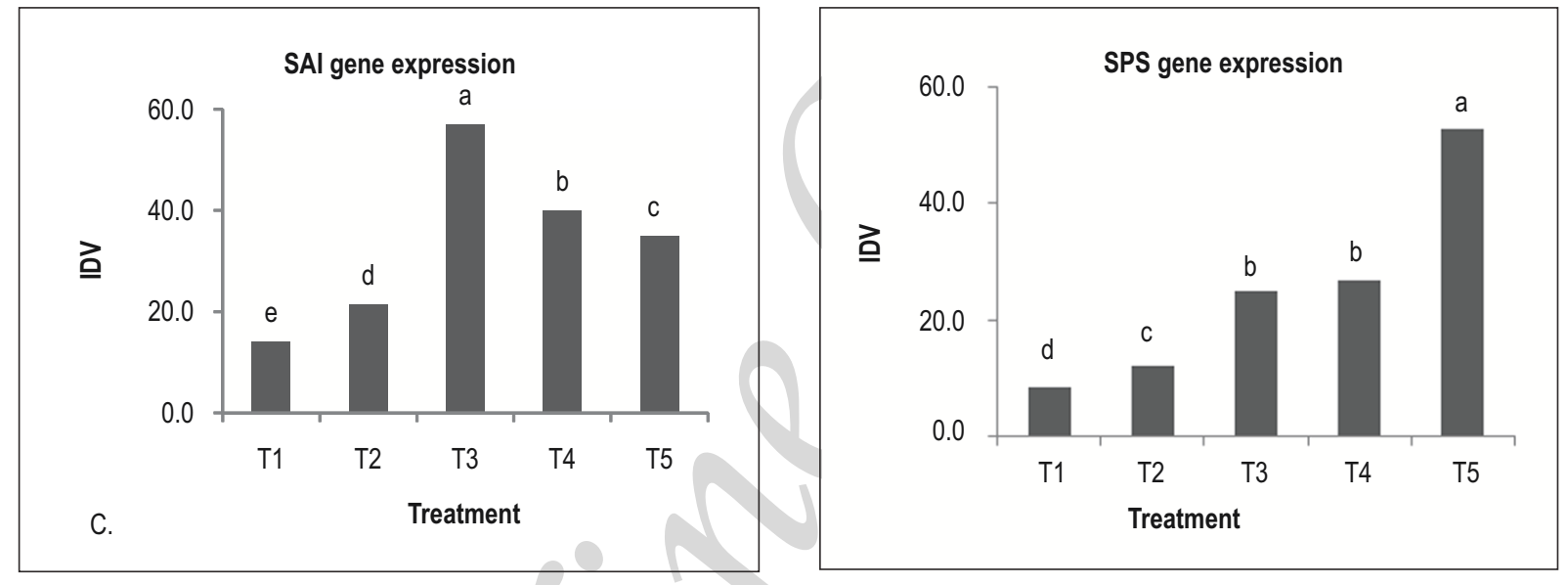

Fig. 3 : Expression pattern of SAl gene in sprouted buds and SPS gene in leaf tissues of sugarcane plants exposed to graded levels of Ethephon. (A,B); PCR products separated on $1.2 \%$ agarose gel stained with ethidium bromide and visualized with gel documentation system (Alpha Innotech, USA); Band intensity of PCR product was quantified in terms of Integrated density value (IDV). Mean values with different letters indicate significant $(P=0.05)$ differences between treatments. T1: control, T2: water, T3 : Ethephon 100 ppm, T4 : Ethephon 200 ppm and T5 : Ethephon 400 ppm (C)

investigation, an effort was also made to study the effect of ethephon on SAI gene expression in bud tissues and SPS gene expression in leaf using gene specific primer pairs. Results obtained indicated increase in SAI and SPS gene expression due to ethephon treatment; highest increase in SAI gene was obtained at $100 \mathrm{ppm}$ in bud tissues and SPS gene at $400 \mathrm{ppm}$ ethephon level in leaf (Fig 3). Jain et al. (2013) reported that ethephon shows modulating effect on sucrose metabolizing enzymes, catalyzing synthesis and breakdown of sucrose thus helps in improving growth and sucrose accumulation in sugarcane. Increase in SAI gene expression in bud tissues at 100 ppm ethephon might be due to stimulatory effect of ethephon on respiratory activity of germinating tissues (bud) and higher SAI activity at low ethephon concentration. While in leaf tissues, SPS was highest at $400 \mathrm{ppm}$ indicating higher concentration of ethephon requirement when applied through foliar application for source (leaf) activity. Leaf maturity and aging may be accelerated by increasing ethylene production using higher concentration of ethephon which promotes the expression of SPS, SS and NI and inhibits SAl enzymes (Wang et al., 2013; Yang et al., 2014). Manipulation at gene level of treated plants might have led to an up-regulation of sucrose synthesis and its accumulation (Joshi et al., 2011; Yang et al., 2014). Available evidences indicated that the ethylene is a concentration dependent biphasic growth modulator in higher plants (Pierik et al., 2006) and sustained response may be achieved by continuous exposure to the growth hormone (Fiorani et al., 2002)

The findings of the present study suggests that low concentration of Ethephon (100 and 200 ppm) enhanced rate of bud sprouting, shortened sprouting time and stimulated plant vigor by modulating the activity of sugar and nitrate metabolizing enzymes, photosynthetic pigments and proline contents. Thus, the sequential application of ethephon at the 
time of planting by setts soaking and through foliar application at early growth stage might be beneficial for promoting morphophysiological development and improving bud sprouting. Biochemical parameters such as sugars, chlorophyll, phenol, proline contents, activity NR enzyme and expression of SAI and SPS gene are found to be beneficially affected by the application of ethephon at low concentration.

\section{Acknowledgment}

Authors would like to thank the Director, ICAR-Indian Institute of Sugarcane Research, Lucknow, India for his guidance, support and encouragement.

\section{References}

Almazan, O., L. Gonzalez and L. Galvez: The sugarcane, it's by-products and co-products. Sugarcane 19, 3-8 (2001).

Arnon, D.I.: Copper enzymes in isolated chloroplasts: polyphenol oxidase in Beta vulgaris. Plant Physiol., 24, 1-15 (1949).

Ashraf, M., and M.R. Foolad: Roles of glycine betaine and proline in improving plant abiotic stress resistance. Environ. Exp. Bot. 59, 206-216 (2007).

Bates, L.S., R.P Waldren and I.D. Teare: Rapid determination of free proline in water stress studies. Plant Soil, 39, 205-208 (1973).

Chandra, A., R. Jain, R.K. Rai and S. Solomon: Designing and application of sucrose controlling enzyme soluble acid invertase (SAI) gene based primer pairs in sugarcane. Nati. Acad. Sci. Lett., 33, 355-359 (2010).

Cunha, C.P., G.G. Roberto, R. Vicentini, C.G. Lembke, G.M. Souza, R.V. Riberio, E.C. Machado, Ana M.M.A. Lagoa and M. Menossi: Ethylene induced transcriptional and hormonal responses at the onset of sugarcane ripening. Scientific Reports, $7: 43364$. DOI: 10.1038/ srep 43364 (2017).

Dai, H., M. Fu, X. Yang and Q. Chen: Ethylene inhibited sprouting of potato tubers by influencing the carbohydrate metabolism pathway. J. Food Sci. Technol. 53, 3166-3174 (2016).

Dash, M. and S.K. Panda: Salt stress induced changes in growth and enzyme activities in germinating Phaseolus mungo seeds. Biol. Plant., 44, 587-589 (2001).

Fiorani, F., G.M. Bogemann, E.J.W. Visser, H. Lambers and L.A.C.J. Voesenek: Ethylene emission and responsiveness to applied ethylene vary among Poa species that inherently differ in leaf elongation rates. Plant Physiol., 129, 1382-1390 (2002).

Foukaraki, S.G., K.Cools, G.A. Chope and L.A. Terry: Impact of ethylene and 1-MCP on sprouting and sugar accumulation in stored potatoes. Post Harvest Biol. Technol., 114, 95-103 (2012).

Grewal, H.S., J.S. Kolar, S.S. Cheema and G. Singh: Studies on the use of growth regulators in relation to nitrogen for enhancing sink capacity and yield of gobhi-serson (Brassica napus). Indian J. Plant Physiol., 36, 1-4 (1993).

Iqbal, N., S. Umar, T. S. Per and N. A. Khan: Ethephon increases photosynthetic-nitrogen use efficiency, proline and antioxidant metabolism to alleviate decrease photosynthesis under salinity stress in mustard. Plant Signaling Behavior, DOI : 10.1080/ 15592324. 2017.1297000 (2017).

Ingemarsson, B.S.M.: Ethylene effects on peroxidases and cell growth pattern in Picea abies hypocotyls cuttings. Physiol. Plant., 94, 211218(1995).

Jain, R., A. Chandra and S. Solomon: Impact of exogenously applied enzymes effectors on sucrose metabolizing enzymes (SPS, SS and SAI) and sucrose content in sugarcane. Sugar Tech., 15 , 370-378 (2013).

Jain, R. and S. Solomon: Growth stimulating effect of ethephon on sprouting and early vigor of sugar cane bud chips. Sugarcane, 28, 14-18 (2010).

Jain, R., S. Solomon, A.K. Shrivastava and A. Chandra: Effect of ethephon and calcium chloride on growth and biochemical attributes of sugarcane bud chips. Acta Physiol. Plant, 33, 905-910 (2011).

Jain, R., S. Solomon, Y.R. Li and A.K. Shrivastava: Ethephon: Impact on sugarcane physiology and sugar productivity. Agrotech Publishing Academy (2014).

Joshi, G., A. Shukla and A. Shukla: Synergistic response of auxin and ethylene on physiology of Jatropha curcas L. Braz. J. Plant Physiol., 23, 67-77, (2011).

Ke, D. and M.E. Saltveith: Plant hormone interaction and phenolic metabolism in the regulation of russet spotting in iceberg lettuce. Plant Physiol., 88, 1136-1140 (1988).

Khan, N. A.: The influence of exogenous ethylene on growth and photosynthesis of mustard (Brassica juncea) following defoliation. Sci. Hortic., 105, 499-505 (2005).

Khan, N.A., M.R. Mir, R. Nazar and S. Singh : The application of ethephon (an ethylene releaser) increases growth, photosynthesis and nitrogen accumulation in mustard (Brassica juncea L.) under high nitrogen levels. Plant Biol. 10, 534-538 (2008).

Khan, M.I. R., A. Trivellini, M. Fatma, A. Masood, A. Francini, N. Iqbal, A. Ferrante and A. Nafees: Role of ethylene in responses of plants to nitrogen availability. Front Plant Sci. 6, 927 (2015).

Kidd, H. and D.R. James : The Agrochemicals Handbook. $3^{\text {rd }}$ Edn., Royal Society of Chemistry Information Services. Cambridge, UK. 10-2 (AS update) (Eds.) (1991).

Leite, G.H.P., C.A.C. Crusciol, G.P.P. Lima and M.A. Silva: Growth regulators and activity invertases in the middle of the cropping season. Ciencia Rural, Santa Maria, 39, 718-725 (2009) (in Portuguese).

$\mathrm{Li}$, Y.R.: Beneficial effects of ethephon application on sugarcane under sub-tropical climate of China. Sugartech., 6, 235 (2004).

Lidija, B., H. Lepeduš, I. Štolfa, Z. Jurković, J. Kovačević and V. Cesar: Involvement of peroxidases in structural changes of barley stem. Bragantia, 76, doi.org/10.1590/1678-4499.155 (2017).

Liu, H.K., Y. Lao, W.N. Huang, Y.D. Guo and Y.F. Kang: Effect of ethylene on total phenolics, antioxidant activity and the activity of metabolic enzymes in mung bean sprouts. Eur. Food Res. Technol. 237, 755764 (2013).

Love, J., S. Björklund, J.Vahala, M. Hertzberg, J. Kangasjärvi and B. Sundberg: Ethylene is an endogenous stimulator of cell division in the cambial meristem of Populus. Proc. Natl. Acad. Sci. USA. 106, 5984-5989 (2009).

Luck, H.: Peroxidase. In: Method in Enzymatic Analysis. (Ed : H.U. Bergmeyer). Academic Press, New York and London. pp. 895-897 (1963).

Luo, R.B., Y.R. Li and Y.K. Lin: Effects of ethephon sprayed at early growth stage on ultrastructure of chloroplast in sugarcane. $J$. Guangxi Agric. Univ. 16, 192-197 (1997).

Ozurtk, L. and Y. Damir: Effects of putrescine and ethephon on some oxidative stress enzyme activities and proline content in salt stressed spinach leaves. Plant Growth Regul., 40, 89-95 (2003).

Palmer, C.E.: Influence of ethephon on nitrate reductase, protein amino nitrogen and nitrate content of Solanum tuberosum L. Plant and Cell Physiol., 26, 407-417, (1985).

Pan, R., J. Wang and X. Tian: Influence of ethylene on adventitious root formation in mung bean hypocotyl cuttings. Plant Growth Regul., $36,135-139$ (2002).

Peng, X.X. and M. Yamauchi: Ethylene production in rice bronzing leaves 
induced by ferrous iron. Plant Soil, 149, 227-234 (1993).

Pierik, R., D. Tholen, H. Poorter, E.J.W. Visser and L.A.C.J. Voesenek: The Janus faces of ethylene : Growth inhibition and stimulation. Trends Plant Sci., 11, 176-183 (2006).

Pujade-Renaud, V., A. Clement, C. Perrot-Rechenmann, J. C. Prevot, H. Chrestin, J. L. Jacob and J. Guern : Ethylene-induced increase in glutamine synthetase activity and mRNA levels in Hevea brasiliensis latex cells. Plant Physiol., 105, 127-132 (1994).

Qu, L., X. Wang, E. Hood and R. Scalzo: Ethephon promotes germination of Echinacea angustifolia and $E$. pallida in darkness. Hort. Sci., 39,1101-1103 (2004).

Radin, J.W. : In vivo assay of nitrate reductase in cotton leaf discs. Effects of oxygen and ammonium. Plant Physiology, 51, 332-336 (1973).

Retig, N. and J. Rudich : Peroxidase and IAA oxidase activity and isoenzyme patterns in cucumber plants, as affected by sex expression and ethephon. Physiologia Plantarum, 27, 156-160 (1972).

Sari, A.O., M.R. Morales and J.E. Simon: Ethephon can overcome seed dormancy and improve seed germination in purple coneflower species Echinacea angustifolia and E. pallida. Hort Technol., 11, 202-205 (2001).

Solomon, S., K. Singh, S. Bhatnagar and V.K. Madan: Effect of applied ethephon on foliar enzymes of late-planted sugarcane. Indian J. Sugarcane Technol., 5, 61-65 (1988).

Solomon, S., H.N. Shahi, S.K. Duttamajumder, I. Singh and V.K. Madan: Effect of ethephon on sugarcane grown under subtropical climate.
Proceedings International Sugar Cane Technol., 24, 177-179 (2001).

Solomon, S., I. Singh and V.K. Madan: Effect of 2-chloroethyl phosphonic acid on early growth and advancement of maturity in sugarcane. Proceedings of $60^{\text {th }}$ Annual Convention of the Sugar Technologists Association of India, Shimla (1998).

Verma, A.K., S.K. Upadhyay, P.C. Verma, S, Solomon and S.B. Singh: Functional analysis of sucrose phosphate synthase (SPS) and sucrose synthase (SS) in sugarcane (Saccharum) cultivars. Plant Biol., 13, 325-332 (2011).

Wang, A.Q., W.J. Huang, J.Q. Niu, M. Liu, L.T. Yang and Y.R. Li: Effects of ethephon on key enzymes of sucrose metabolism in relation to sucrose accumulation in sugarcane. Sugar Tech., 15, 177-186 (2013).

Yang, L.T., A.Q.Wang, B.Q. Zhang, Y.W. Wei, D.L. Huang, J.Q. Niu and Y.R. Li: Physiological and molecular basis of applying Ethephon to enhance sucrose content in sugarcane. Proc. Intern. Conclave on sugar Crops: Sweetners and Green Energy from sugar Crops: Emerging Technologies. pp. 44-51 (2014).

Yao, R.L., Y.R. Li and L.T. Yang: Effects of ethephon on ripening and increasing sucrose content in mature and immature internodes of sugarcane. Southwest China J. Agricul. Sci., 20, 89-94 (2000) (in Chinese).

Yao, R.L., Y.R. Li, L.T. Yang and Y.P. Ye: Effect of ethephon on the IAA oxidase activity in sugarcane internode. Journal of Guangxi Agricul. Biol. Sci., 19, 6-9 (in Chinese) (2000a). 